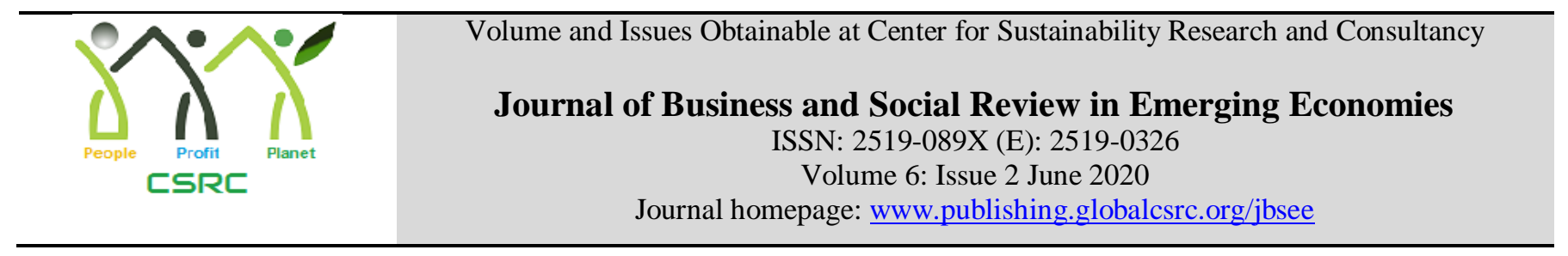

\title{
Nexus of Transformational Leadership and Employees' Job Performance in Telecom Sector Pakistan
}

\section{${ }^{1}$ Altaf Hussain, ${ }^{2}$ Muhammad Asad Khan, ${ }^{3}$ Jawad Hussain, ${ }^{4}$ Mohammad Hanif Khan}

\begin{abstract}
${ }^{1}$ Assistant Professor, Department of Commerce and Management Sciences, University of Malakand, Khyber Pakhtunkhwa, Pakistan,altafhussain@uom.edu.pk

${ }^{2}$ PhD Scholar, Universiti Tun Hussein Onn (UTHM) Malaysia,asadkhanbte06@gmail.com

${ }^{3}$ Associate Professor, Department of Commerce and Management Sciences, University of Malakand, Khyber Pakhtunkhwa, Pakistan,jawadhussain79@gmail.com

${ }^{4}$ Assistant Professor, Department of Tourism and Hotel Management, University of Malakand, Khyber Pakhtunkhwa, Pakistan,hanifyousafzai@uom.edu.pk

\begin{tabular}{l}
\hline ARTICLE DETAILS \\
\hline History \\
Revised format: May 2020 \\
Available Online: June 2020
\end{tabular}

Keywords

Nexus, Transformational leaders, Telecom Sector, job performance, SPSS

JEL Classification

M1, M12

ABSTRACT

Transformational leadership is credited to inspire, motivate and support their employees in order to achieve organizational objectives. These leaders maintain the quality of workforce by inculcating visionary skills and abilities in their subordinates. This paper aims to examine the nexus of transformational leadership with employees' job performance in telecom sector of Pakistan. The data is collected from the employees of PTCL (Pakistan Telecommunications Company Limited) head quarter, Islamabad through questionnaire. Sampling was made using purposive sampling technique. 150 questionnaires were distributed among the employees, out of which 120 were received back recording a response rate of 80 percent. It was hypothesized that transformational leadership is positively associated with employees' job performance. Data is analyzed using correlation and regression analysis through SPSS. Results of the study indicate that majority of the PTCL employees agree that transformational leadership style has significant positive impact on employees job performance. In the light of the findings of this research it is recommended for PTCL management to adopt transformational leadership style to tackle today's dynamic environment.
\end{abstract}

(C) 2020 The authors, under a Creative Commons AttributionNonCommercial 4.0

Corresponding author's email address: altafhussain@uom.edu.pk

Recommended citation: Hussain A., Khan, M. A., Hussain, J., and Khan, M. H. (2020). Nexus of transformational leadership and employees' job performance in telecom sector Pakistan. Journal of Business and Social Review in Emerging Economies, 6(2), 799-806

\section{Introduction}

Sustainable competitive advantage is the need of globalization (Majeed, 2011) which requires both product and system management to be innovative. Various scholars have documented human resource's importance for an organization. They further declared it as a precious asset due to its inimitability and 
creation of sustainable competitive advantage for organization. Sustainable completive advantage is created as a result of innovative ideas of human resources (Ward, Grudnoff, Brooker, \& Simpson, 2013). New innovations become possible when employees get motivated. The credit of motivation of employees goes to leaders who shoulder the responsibility of leading and management of human resource with efficiency and effectiveness (Liaw, Chi, \& Chuang, 2010; Shanker, 2012). The role of leaders is important in such scenario (Chou, Lin, Chang, \& Chuang, 2013). Leaders help maintain and retain quality workforce using their skills and abilities engrained in them (Kwan, 2009). Organizations practice various leadership styles but mostly widely used one in organizations is transformational leadership style adopted for management of change (Kejriwal \& Krishnan, 2004; Sarros \& Santora, 2001). Such leadership style is credited and characterized as a role model as it brings positive and precious changes among its followers by motivating and showing grave concern for each follower (Shibru \& Darshan, 2011; Stewart, 2006). Less authority is exercised by the leader in this style and leader act as a mentor, guide, coach, and stimulator in order to enhance the vision of the followers (Jyoti \& Bhau, 2015). Therefore, Social exchange theory is the premise to establish relationship between the leader and the follower (Carter, Jones-farmer, Armenakis, field, \& Svyantek, 2009). According to the notion of social exchange theory, when one individual gets something valuable from another individual, it becomes obligation for the receiver to respond in the same manner (Blau, 1964) and such reciprocity results in beneficial consequences for both the leader and organizations. It is more likely that followers exchange such benefits with the leaders and their organizations by performing efficiently and effectively for the organizations (Liden, Sparrowe, \& Wayne, 1997).

Numbers of studies have attempted to determine relationship between leadership and employees' job performance but mostly such studies have been conducted in western settings (Anwar \& Ahmad, 2012; El-Zayaty, 2016; Miao, Newman, \& Lamb, 2012). The fact that transformational leadership is successful globally has to explore yet (El-Zayaty, 2016). Hence, there was felt a need to examine relationship between these two variables in developing countries specially Pakistan where studies are scant on such relationship (Anwar \& Ahmad, 2012). Fewer studies have been witnessed on the relationship of these two variables in telecom sector observed as emerging sector of Pakistan in the last decade (Anwar \& Ahmad, 2012). Hence, this study is purposed to find out nexus of transformational leadership with employees' job performance of telecom sector.

\section{Literature Review}

\subsection{Transformational Leadership}

The management literature has acknowledged leadership as a popular notion due to its vital role in the smooth running and success of an organization (El-Zayaty, 2016; Kamisan \& King, 2013). Research scholars view leadership as the extent to which a leader triggers off, inspires and motivates the subordinate under his or her control towards the attainment of some common goals. The pivotal role of leaders has been acknowledged in shaping and protecting the organizational values and demonstrating these values (Dola, 2015; Kolzow, 2014).

According to Burns (1978) leader is one who is capable to infuse and inculcate the purpose to subordinates. Moreover, Burns opined that the leaders and subordinates attempt to support one another that result in rise in morality which keep them motivated. Leaders should possess the attributes of vision and innovativeness. They should believe in provision of opportunities to subordinates so that they learn how to cope with the odd situation in the organization. In addition, they should encourage the subordinates and extend maximum possible support to them so that they may own themselves as part of the organization.

Transformational leadership has been documented as a dominant and popular style of leadership and has gained the attention of the research scholar and policy makers for the last few decades (El-Zayaty, 2016; Judge, Fluegge Woolf, Hurst, \& Livingston, 2006; Odumeru \& Ogbonna, 2013). Burns (1978) was the first who coined the concept of transformational leadership, during his study of political leadership, in 
his book on leadership (Bolden, Gosling, Marturano, \& Dennison, 2003), but the term has been using widely as the popular notion of organizational psychology. Prior research has highlighted as a process that makes the individual competent, capable and vigilant to achieve more than what is expected of him or her and, is linked to values, ethics, emotions and long term goals set by an organization (Dola, 2015).

Burns (1978) describes that transformational leadership reflects the relationship between the subordinates and leaders and defined it as a link that motivate subordinates to accomplish some common objectives, aims and goals. Dubrine in his book leadership (1997) contend that transformational leadership is all about the achievements of the leadership and not on the personal characteristics. Dubrine (1997) opined that the such leaders must possess some salient attribute, These include charisma, excising the inspirational leadership, intellectual stimulation and demonstration of the individuals' concerns (Cossin \& Caballero, 2013). Chemjong (2004) is of the opinion that transformational leaders always concentrate the changing patterns of the organization and make the objectives and goals of the organization clear and achievable.

\subsection{Employees' job performance}

The management literature has highlighted the performance of an employee working in the organization of great concern and valuable for the smooth running and long term success of the organization. Research scholars noted that employees determine the fate of the organization, in that, they decide whether to move forward or step back (Anwar \& Ahmad, 2012). In the same line, prior research demonstrated that employees performance is the foundation to organization success and long term growth (Bartlett \& Ghoshal, 1995). If employees deliver well, it bring prosperity, quality and positive change in the organization that in turn leads to improved organizational performance (Anwar \& Ahmad, 2012). Prior studies have researched the relationship between transformational leadership and employees job performance and found the positive link between these two constructs (Anwar \& Ahmad, 2012; Cavazotte, Moreno, \& Bernardo, 2013). In light of the aforementioned extant literature review, this study aims to further validate the link between the study constructs in a developing country's context like Pakistan.

\subsection{Relationship between Transformational Leadership and Employees' Job Performance}

Prior studies have highlighted certain ways for enhancement of job performance level of employees. Among them leadership style is one that if supportive and dynamic can results in improved employees job performance (Keskes, 2014). Influencing, motivating and molding the behavior of the subordinates facilitate the achievement of organizational objectives and goals (Batista-Taran, Shuck, Gutierrez, \& Baralt, 2013). Review of the extant literature demonstrate the positive linkage between the transformational leadership and employees job performance (Anwar \& Ahmad, 2012). The review of the prior meta analyses also support the positive link between these constructs (Judge \& Piccolo, 2004; Lowe, Kroeck, \& Sivasubramaniam, 1996; Patterson, Fuller, Kester, \& Stringer, 1995). In the same line, a study conducted in the banking sector postulated that transformational leadership is significantly positively associated with employees' job performance (Geyer \& Steyrer, 1998). Research scholars have noted that the transformational style of leadership in an organization enhances the innovative capabilities of the employees that in turn results enhanced employees performance and improved productivity (Howell \& Avolio, 1993). A study undertaken on Brazilian employees' also reported that transformational leadership is positively linked with employees' job performance (Cavazotte et al., 2013). On the basis of the aforementioned review of the literature, positive relationship of transformational leadership with employees' job performance is hypothesized. 


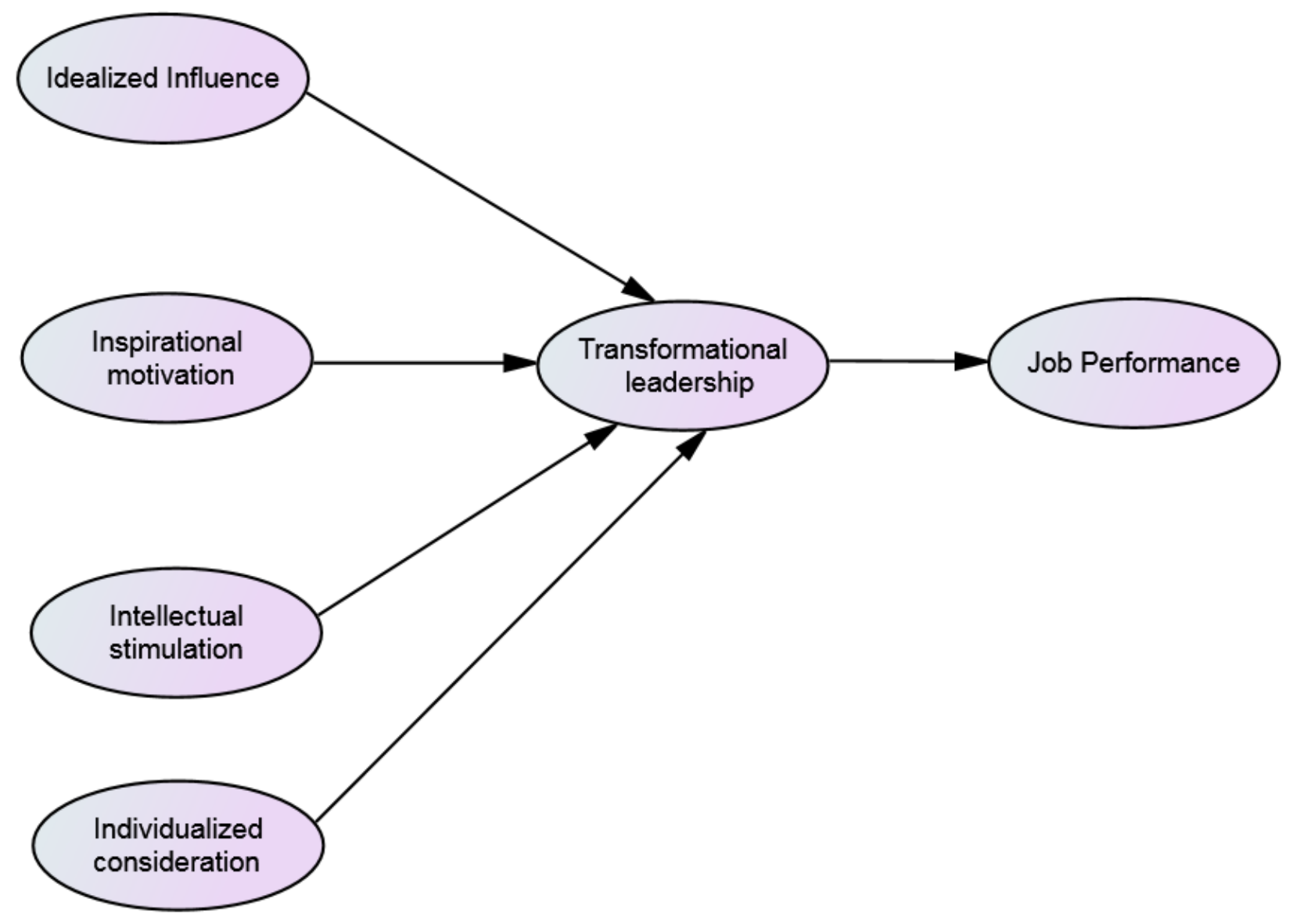

Figure 1: Research framework of the study

\section{Materials and methods}

For data collection management and lower level employees of PTCL headquarter, Islamabad were selected. Sampling was made using purposive sampling technique. 150 questionnaires were handed over to employees, out of these 120 filled questionnaires were received back recording response rate of 80 percent. Five point Likert scale was used to record responses of the respondents. SPSS-22 was used to run the regression and correlation analysis.

\subsection{Transformational leadership scale}

For measuring transformational leadership variable, 20 items scale was utilized taken from study of Bass and Avolio (1989). This scale had four dimensions for measurement i.e. idealized influence, inspirational motivation, intellectual stimulation and individualized consideration. Reliability of the scale was established having Cronbach's alpha of 0.90 . For wording items five point Likert scale ranging from (1) "strongly disagree" to (5) strongly agree was employed.

\subsection{Job Performance scale}

For measuring Job performance variable, 5 items scale were employed taken from study of Goodman and Svyantek (1999). The scale was measured utilizing task and contextual performance. Reliability of the scale was established having Cronbach's alpha of 0.89 . for wording items of the scale five point Likert scale ranging from (1) "strongly disagree" to (5) "strongly agree" was employed.

\section{Results and discussion}

The study was aimed to investigate nexus of transformational leadership and employees' job performance in telecom sector. Correlation and regression analysis were run to analyze data of the study. 
Table 01

\begin{tabular}{cccc}
\hline \multicolumn{3}{c}{ Correlations of transformational leadership and job performance } \\
\hline \multirow{3}{*}{ Pearson Correlation } & Performance & Transformational Leadership \\
& Performance & 1.000 & .831 \\
& $\begin{array}{c}\text { Transformational } \\
\text { Leadership }\end{array}$ & .831 & 1.000 \\
Sig. (1-tailed) & $\begin{array}{c}\text { Performance } \\
\text { Transformational } \\
\text { Leadership }\end{array}$ & .000 & .000 \\
& $\begin{array}{c}\text { Performance } \\
\text { Transformational } \\
\text { Leadership }\end{array}$ & 120 &. \\
& 120 & 120 \\
\hline
\end{tabular}

Correlation analysis was conducted in order to operationalize the hypothesis. The correlation coefficient of 0.831 indicates strong positive relationship of transformational leadership with employees' job performance (Refer Table 01).

Table 02

Model Summary of transformational leadership and job performance

\begin{tabular}{|c|c|c|c|c|c|c|c|c|c|}
\hline \multirow[b]{2}{*}{ Model } & \multirow[b]{2}{*}{$\mathrm{R}$} & \multirow[b]{2}{*}{ R Square } & \multirow{2}{*}{$\begin{array}{l}\text { Adjusted R } \\
\text { Square }\end{array}$} & \multirow{2}{*}{$\begin{array}{l}\text { Std. Error of the } \\
\text { Estimate }\end{array}$} & \multicolumn{5}{|c|}{ Change Statistics } \\
\hline & & & & & R Square Change & F Change & df1 & df 2 & Sig. F Change \\
\hline 1 & $.811^{\mathrm{a}}$ & .685 & .681 & .481 & .685 & 202.113 & 1 & 99 & .000 \\
\hline
\end{tabular}

The value of $\mathrm{R}^{2}$ shows that the independent variable (transformational leadership) is explaining the dependent variable (job performance) up to $68 \%$. The value of $\mathrm{R}$ square is (.685) which means that $68 \%$ change occur in dependent variable (job performance) due to independent variable (transformational leadership). There are also some other factors which contribute to the increase in employees' job performance but overall the model is significant (Refer Table 02).

\section{Table 03}

\begin{tabular}{|c|c|c|c|c|c|c|}
\hline \multicolumn{7}{|c|}{ ANOVA between transformational leadership and job performance } \\
\hline & Model & Sum of Squares & Df & Mean Square & $\mathrm{F}$ & Sig. \\
\hline \multirow[t]{3}{*}{1} & Regression & 47.895 & 1 & 48.985 & 202.113 & $.000^{\mathrm{a}}$ \\
\hline & Residual & 22.591 & 97 & .242 & & \\
\hline & Total & 70.486 & 98 & & & \\
\hline \multicolumn{7}{|c|}{ a. Predictors: (Constant), Leadership } \\
\hline \multicolumn{7}{|c|}{ b. Dependent Variable: Performance } \\
\hline
\end{tabular}

The F statistic 202.13 indicates that the two variables of the study are strongly related having optimal significance value 0.000 (Refer Table 03), which led to the acceptance of hypothesis formulated on the positive relationship of transformational leadership with employees' job performance. 


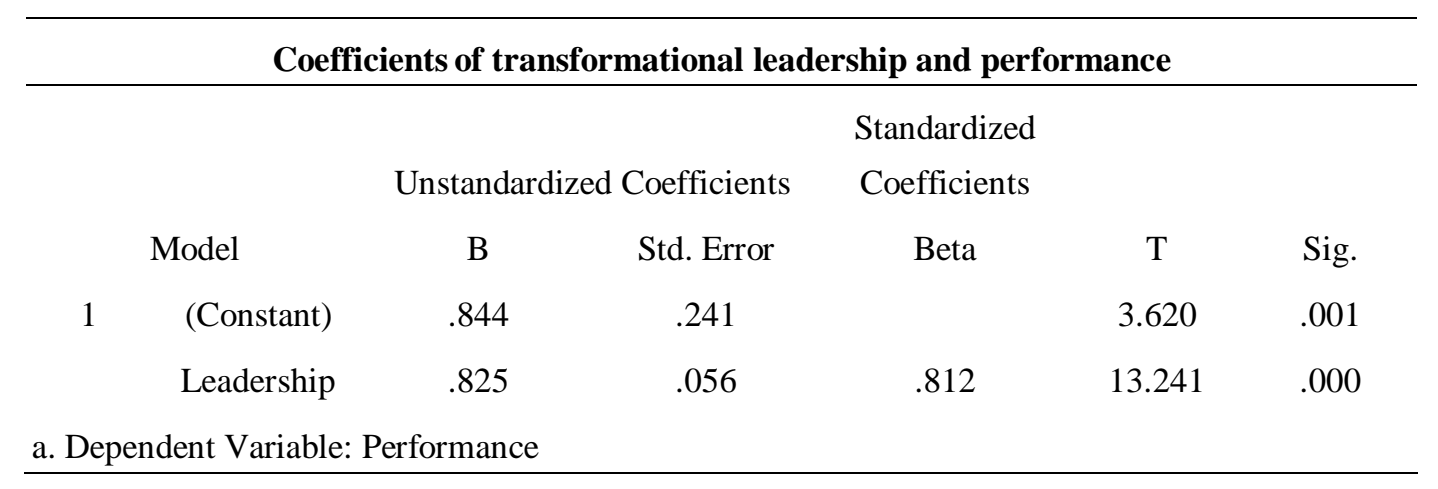

The Beta $(\beta)$ value $=.812$ for these variables shows that one unit increase in independent variable (transformational leadership) will increase the dependent variable (job performance) by 0.8 units (Refer Table 04).

So the results of the study are in congruence with the results of previous studies (Anwar \& Ahmad, 2012; Cavazotte et al., 2013) showing positive effect of transformational leadership on the employees' job performance. Characteristics of transformational leadership in the form of idealized influence, inspirational motivation, intellectual stimulation and individual considerations help the leaders to create good relationships with the followers which in turn motivate them to perform better in the organizations (Jyoti \& Bhau, 2015).

\section{Conclusion, recommendations and limitations}

Transformational leadership helps employees to enhance their job performance by giving them opportunity of self-development and more learning in the organization. Transformational leaders create an environment where employees achieve organizational goals through mutual trust and harmony. Achievement of organizational goals becomes feasible as these leaders in the form of change agents transform their followers' behaviors, attitudes, beliefs and motivation. Transformational leaders inculcate vision and emotional relationship in their followers. Findings of the study report that majority of the employees in PTCL head quarter Islamabad is convinced regarding the positive association of transformational leadership with employees' job performance. In order words, transformational leaders increase employees' job performance. Previous studies support such notion of enhancement in employees' job performance through transformational leadership (Anwar \& Ahmad, 2012; Cavazotte et al., 2013).

The importance and role of transformational leader is increased and demanded in today's changing environment. Those organizations who use their human resource efficiently and effectively gain competitive advantage as compared to other organizations. Leadership style has a key role in both individual and organizational performance. Henceforth, in light of the results of the study it is strongly recommended that PTCL management should adopt transformational leadership style to tackle fast changing environment. It is also recommended that leader should invest on the development of their employees' talent by providing supportive and flexible environment. The transformational leaders should be considerate to their employees' needs, desires and abilities. Taking of all these recommendations into consideration will help achieve performance standards set by organizations. Personality and gender affect this relationship differently, so future studies can use these variables as moderators in such relationship.

This study has used cross sectional research design collecting data at one point of time. Data is collected only from employees PTCL head quarter, Islamabad. Data collected is based on judgments and perceptions of employees so subjectivity factor can be an element.

\section{References}

Anwar, Farooq, \& Ahmad, Ungku Norulkamar Ungku. (2012). Mediating role of organizational 
commitment among leadership styles and employee outcomes. an empirical evidence from telecom sector of Pakistan. International Journal of Research in Economics \& Social Sciences, 2(3), 116-151.

Bartlett, Christopher A, \& Ghoshal, Sumantra. (1995). Changing the role of top management: beyond systems to people. Long Range Planning, 4(28), 126.

Bass, B. M, \& Avolio, B. J. (1989). Manual: The multifactor leadership questionnaire. Palo Alto, CA: Consulting Psychologists Press:

.Batista-Taran, Laura C, Shuck, Michael Bradley, Gutierrez, Cinthya C, \& Baralt, Sofia. (2013). The role of leadership style in employee engagement.

Blau, Peter Michael. (1964). Exchange and power in social life: Transaction Publishers.

Bolden, Richard, Gosling, Jonathan, Marturano, Antonio, \& Dennison, Paul. (2003). A review of leadership theory and competency frameworks: Centre for Leadership Studies, University of Exeter.

Burns, J.M.G. (1978). Leadership: Harper \& Row.

Carter, min z, Jones-farmer, allison, Armenakis, achilles a, field, hubert s, \& Svyantek, daniel j. (2009). Transformational leadership and followers'performance: Joint mediating effects of leadermember exchange and interactional justice. Paper presented at the Academy of Management Proceedings.

Cavazotte, Flávia, Moreno, Valter, \& Bernardo, Jane. (2013). Transformational leaders and work performance: the mediating roles of identification and self-efficacy. BAR-Brazilian Administration Review, 10(4), 490-512.

Chemjong, M. (2004). Transactional or transformational leader. Spot light, 24(2), 261-263.

Chou, Huey-Wen, Lin, Yu-Hsun, Chang, Hsiu-Hua, \& Chuang, Wen-Wei. (2013). Transformational Leadership and Team Performance. SAGE Open, 3(3), 2158244013497027.

Cossin, D, \& Caballero, J. (2013). Transformational Leadership, background literature review. Retrieved March.

Dola, Grace Akoth. (2015). The Effect of Transformational Leadership on the Performance of Employees in Kenya: The Case of Kenya Wildlife Service. Kenyatta University.

DuBrin, A.J. (1997). 10 Minute Guide to Effective Leadership: Macmillan Spectrum/Alpha Books.

El-Zayaty, Nady Ahmed. (2016). An Exploration of Leadership Styles and Motivation in Egyptian Business Organizations.

Geyer, Alois, \& Steyrer, Johannes. (1998). Messung und Erfolgswirksamkeit transformationaler Führung. German Journal of Human Resource Management: Zeitschrift für Personalforschung, 12(4), 377-401.

Goodman, Scott A, \& Svyantek, Daniel J. (1999). Person-organization fit and contextual performance: Do shared values matter. Journal of Vocational Behavior, 55(2), 254-275.

Howell, Jane M, \& Avolio, Bruce J. (1993). Transformational leadership, transactional leadership, locus of control, and support for innovation: Key predictors of consolidated-business-unit performance. Journal of applied psychology, 78(6), 891.

Judge, Timothy A, Fluegge Woolf, Erin, Hurst, Charlice, \& Livingston, Beth. (2006). Charismatic and transformational leadership: A review and an agenda for future research. Zeitschrift für Arbeitsund Organisationspsychologie A\&O, 50(4), 203-214.

Judge, Timothy A, \& Piccolo, Ronald F. (2004). Transformational and transactional leadership: a metaanalytic test of their relative validity. Journal of applied psychology, 89(5), 755.

Jyoti, Jeevan, \& Bhau, Sonia. (2015). Impact of Transformational Leadership on Job Performance. SAGE Open, 5(4), 1-13.

Kamisan, Arif P, \& King, Brian EM. (2013). Transactional and transformational leadership: A comparative study of the difference between Tony Fernandes (Airasia) and Idris Jala (Malaysia Airlines) leadership styles from 2005-2009. International Journal of Business and Management, $8(24), 107$.

Kejriwal, Aditi, \& Krishnan, Venkat R. (2004). Impact of Vedic worldview and Gunas on transformational leadership. Vikalpa, 29(1), 29-40. 
Keskes, Imen. (2014). Relationship between leadership styles and dimensions of employee organizational commitment: A critical review and discussion of future directions. Intangible Capital, 10(1), 26-51.

Kolzow, David R. (2014). LEADING FROM WITHIN: Building Organizational Leadership Capacity.

Kwan, Paula. (2009). Beginning teachers' perceptions of school human resource practices. Asia Pacific Journal of Education, 29(3), 373-386.

Liaw, Yuann-Jun, Chi, Nai-Wen, \& Chuang, Aichia. (2010). Examining the mechanisms linking transformational leadership, employee customer orientation, and service performance: The mediating roles of perceived supervisor and coworker support. Journal of Business and Psychology, 25(3), 477-492.

Liden, Robert C, Sparrowe, Raymond T, \& Wayne, Sandy J. (1997). Leader-member exchange theory: The past and potential for the future. Research in personnel and human resources management, 15, 47-120.

Lowe, Kevin B, Kroeck, K Galen, \& Sivasubramaniam, Nagaraj. (1996). Effectiveness correlates of transformational and transactional leadership: A meta-analytic review of the MLQ literature. The leadership quarterly, 7(3), 385-425.

Majeed, Sadia. (2011). The impact of competitive advantage on organizational performance. European Journal of Business and Management, 3(4), 191-196.

Miao, Qing, Newman, Alexander, \& Lamb, Peter. (2012). Transformational leadership and the work outcomes of Chinese migrant workers: The mediating effects of identification with leader. Leadership, 8(4), 377-395.

Odumeru, James A, \& Ogbonna, Ifeanyi George. (2013). Transformational vs. transactional leadership theories: Evidence in literature. International Review of Management and Business Research, 2(2), 355 .

Patterson, Coleman, Fuller, JB, Kester, K, \& Stringer, DY. (1995). A meta-analytic examination of leadership style and selected compliance outcomes. Paper presented at the 10th Annual Conference of the Society for Industrial and Organizational Psychology, Orlando, FL.

Sarros, James C, \& Santora, Joseph C. (2001). The transformational-transactional leadership model in practice. Leadership \& organization development journal, 22(8), 383-394.

Shanker, Meera. (2012). Organizational citizenship Behavior: Leveraging effects on Transformational Leaders' Emotional Intelligence. Aweshkar Research Journal, 13(1).

Shibru, Bekele, \& Darshan, GM. (2011). Effects of transformational leadership on subordinate job satisfaction in leather companies in Ethiopia. International Journal of Business Management \& Economic Research, 3(5).

Stewart, Jan. (2006). Transformational leadership: An evolving concept examined through the works of Burns, Bass, Avolio, and Leithwood. Canadian Journal of Educational Administration and Policy, 54, 1-29.

Ward, Lorrae, Grudnoff, Lexie, Brooker, Barry, \& Simpson, Mary. (2013). Teacher preparation to proficiency and beyond: Exploring the landscape. Asia Pacific Journal of Education, 33(1), 6880 . 